\title{
Threatened endemic species of Hibiscus L. (Malvaceae) in Minas Gerais, Brazil
}

Hibiscus L. is one of the largest genera of Malvaceae, Southeast Brazil has six endemic species of the 14 native species, mainly distributed in Cerrado. These Hibiscus are hairy shrubs, with showy flowers of pink corolla, dark base, 5 -toothed staminal tube apex, loculicidal capsule of 5 cells. The species inhabit wet ecosystems of the Atlantic Rainforest and Cerrado. After the last study of Hibiscus taxonomy that evidencied four endemic species in Minas Gerais, this state showed to have the largest endemism center of Hibiscus in Brazil, therefore, using IUCN classification methodology, we indicated $\mathrm{H}$. hilarianus and $\mathrm{H}$. multiformis as vulnerable, $\mathrm{H}$. itirapinensis as endangered and $\mathrm{H}$. mariae as critically endangered. The species are represented by small isolated populations, distributed at the mountains and plateaus between the Espinhaço mountain range and Paulista plains, in a region with great endemic biodiversity. According to the previously a is recommended specific studies to research the evolutionary context of Hibiscus species in Minas Gerais state. We also suggest the attention to the threatened endemic species distributed in Conservation Units, when it is not distributed in protected areas is strongly recommended its creation.

Palavras-chave: Threatened Species; Minas Gerais; Cerrado; Cabral Mountain Range; Espinhaço Mountain Range.

\section{Espécies endêmicas ameaçadas de Hibiscus L. (Malvaceae) em Minas Gerais, Brasil}

\begin{abstract}
Hibiscus L. é um dos maiores gêneros de Malvaceae, o Sudeste do Brasil possui seis espécies endêmicas de 14 espécies nativas, distribuídas principalmente no Cerrado. Estes Hibiscus são arbustos pilosos, de flores vistosas com corola rosa de base escura, ápice do tubo estaminal 5-dentado, cápsula loculicida com cerca de 5 sementes. As espécies habitam ecossistemas úmidos da mata atlântica e cerrado. Após o último estudo da taxonomia de Hibiscus, foram evidenciados quatro espécies endêmicas de Minas Gerais, este estado mostrou ter o maior centro de endemismo de Hibiscus no Brasil, portanto, utilizando os critérios da IUCN indicamos como vulneráveis $\mathrm{H}$. hilarianus e $\mathrm{H}$. multiformis, como ameaçados de extinção, H. itirapinensis, e criticamente ameaçado, $\mathrm{H}$. mariae. As espécies são representadas por pequenas populações isoladas, distribuídas nas montanhas e planaltos entre a Serra do Espinhaço e o Planalto Paulista, considerada uma região de grande biodiversidade endêmica. Recomendam-se estudos específicos para pesquisar o contexto evolutivo das espécies de Hibiscus no estado de Minas Gerais. Também sugerimos a atenção às espécies ameaçadas endêmicas distribuídas em Unidades de Conservação, quando não distribuída em áreas protegidas, é fortemente recomendada a sua criação.
\end{abstract}

Keywords: Espécies Ameaçadas; Minas Gerais; Cerrado; Serra do Cabral; Serra do Espinhaço.

Topic: Conservação da Biodiversidade

Reviewed anonymously in the process of blind peer
Received: 05/03/2019

Approved: 10/05/2019
Luccas Henrique Gomes Rigueiral (iD) Universidade de Mogi das Cruzes, Brasil http://lattes.cnpq.br/7108743641214596 http://orcid.org/0000-0001-5379-5669 Irigueiral@hotmail.com

Victor Martins Gonçalez Universidade de Mogi das Cruzes, Brasil http://lattes.cnpq.br/0390749998479282 vmgoncalez@hotmail.com

\section{Marília Cristina Duarte}

Universidade de Mogi das Cruzes, Brasil http://lattes.cnpq.br/7862572681469243 mariliacd@umc.br

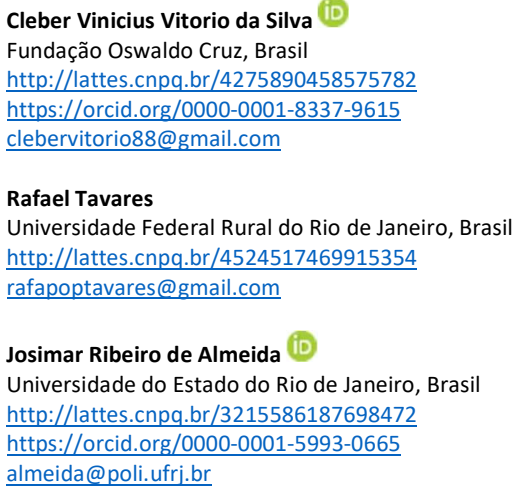

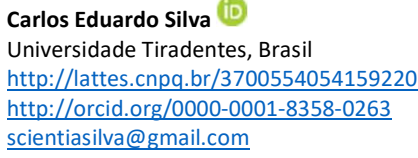

Referencing this:

RIGUEIRAL, L. H. G.; GONÇALEZ, V. M.; DUARTE, M. C.; SILVA, C. V. V.; TAVARES, R.; ALMEIDA, J. R.; SILVA, C. E.. Threatened endemic species of Hibiscus I. (Malvaceae) in Minas Gerais, Brazil. Environmental Scientiae, v.1, n.1, p.9-15, 2019. DOI:

http://doi.org/10.6008/CBPC2674-6492.2019.001.0002 


\section{INTRODUCTION}

In the state of Minas Gerais, the biomes are represented by different ecosystems constituted by plant communities, identified according to their set of species, distribution, different elevations areas, soil types and atmosphere humidity. The Atlantic Rainforest has the following phytophysiognomies: Seasonal Semidecicual Forest and Dense Ombrophilous Forest with its divisions (Alluvial Lowlands, Lowlands, Submontane, Montane and Higher Montane). In the Cerrado biome we considered: Grasslands, Dirty Grasslands, Savannas, Cerradão and Rocky Grasslands, characterizing a high ecological diversity. (RODRIGUES et al., 2017; SILVA et al., 2013; TAVARES et al., 2013).

The Atlantic Rainforest biome had approximately $1,300,000 \mathrm{~km}^{2}$ of extension, and now is reduced to $162,666 \mathrm{~km}^{2}$, the equivalent to $12.4 \%$ of its original forest cover, as today has many uses, some of them being: the remaining forest, planted forests (mainly pinus and eucalyptus), pastures and agricultural crops of annual and perennial plants. The law № 11.428/2006 determines the area of protection of the biome for the 17 states of the federation, which corresponds to $38 \%$ of the Brazilian territory (INPE, 2018).

However, the Atlantic Rainforest biome has one of the largest biodiversity in the planet, with high concentrations of endemic species (BERGALLO et al., 2016) and a high level of degradation. Thus, is possible to consider it as a hotspot, being the conservation of its natural resources of utmost importance to mankind. The Cerrado also has a high endemism, but in the last 50 years the Cerrado has undergone an intense process of vegetative decharacterization, due to the agricultural expansion with focus on soybean, livestock and implementation of real estate and industrial development.

Malvaceae family has about 88 genera and 2.500 species distributed in tropical, neotropical, subtropical and temperate regions, especially in South America. The largest genera are Pavonia, with approximately 225 species, followed by Hibiscus, Abutilon and Sida, with about 150 and 200 species, respectively (LORENZI, 2014).

Hibiscus was first described by Lineaus (1753) in the first edition of Species Plantarum, is one of the largest genera within Malvaceae, represented by approximately 300 species distributed in subtropical, tropical and temperate regions. Exotic ornamental species such as Hibiscus rosa-sinensis L. are better known because of their commercial introduction, however, Brazil has beautiful native species of great value for biodiversity (JUDD et al. 2009).

Brazil is represented by 33 native species occurring in all regions, 25 are endemic, the Brazil Southeast is the second richest region, with 14 species distributed from the Atlantic Rainforest until its transition to the Cerrado, where it occurs in open formations, frequently on rocky grasslands. Among the Brazilian biogeographic domains, the Cerrado is the most representative with 27 species in different ecosystems (Esteves 2015).

According to Rigueiral (2017), Minas Gerais presents 12 species, with four endemic species represented by small isolated populations distributed on the mountains and plateaus between Espinhaço 
mountain range and Paulista plains, considered a region of great endemic biodiversity, therefore, the objective of this study was to evaluate the conservation status of these species.

\section{MATERIAL AND METHODS}

Minas Gerais presents greats endemism centers of Brazil, this state is characterized by a mosaic of distinct vegetations related to the Atlantic Rainforest and Cerrado, whose geological diversity of Espinhaço mountain range and Canastra mountain range may have facilited the isolation of pre-existing populations, acting as favorable environments to speciation (RAPINI et al. 2008).

According to Rigueiral (2017), the species of Hibiscus are sparsely distributed and inhabit ciliate forests of Rocky Grasslands in the Cerrado, where there is a great supply of water. There are few registers in herbarium collections, so they are considered rare. Taxonomy and phylogeny papers about to the Hibiscus genus were consulted. Online surveys were conducted made through vegetation platforms such as Trópicos ${ }^{1}$, Reflora - Flora do Brasil 2020 and Splink³.

The geographic distribution map was made using the program Q-gis 2.16.0, applying geographical coordinates obtained through the herbaria exsiccates and online data (Splink). The IUCN criteria (2012) were used to determine the conservation status of the species, evaluation of their population trend and evaluation of the best conservation measures for the species.

The distribution area was calculated using the Google Maps distance meter tool (2016). The morphological characters were written based on Gonçalves et al. (2011), the small characters such as trichomes were called "tiny" when smaller than one millimeter.

The plants were taxonomically circumscribed through the studies of Rigueiral (2017), who synonymized Hibiscus cabralensis to Hibiscus hilarianus, distinguishing morphologically all the species even with the proximity of their occurrence areas, some overlapping in part.

\section{RESULTS AND DISCUSSIONS}

For having a rich flora and selective adaptations to the climatic and pedological conditions, the floristic diversity of mountain ranges is unique, possessing in its community unusual and rare species. According to Matarazzo et al. (2017), the habitat fragmentation, biopiracy and irrational ecological tourism are the three main factors in the decline of endemic biodiversity of mountain ranges.

The value of the all endemic biodiversity is incalculable, because they are very important to the ecosystems balance, ecological tourism and original landscape preservation, so the financial losses for the local populations can be very high when there is a decrease in biodiversity.

Hibiscus mariae Krapov. was listed as critically endangered, having only the single holotype occurrence site, on the Serra do Cabral mountain range near Rio Preto (MG), justifying its high-risk

\footnotetext{
${ }^{1}$ www.tropicos.org

${ }^{2}$ www.floradobrasil.jbrj.gov.br

${ }^{3}$ www.splink.cria.org.br 
conservation status. This species can be recognized by the presence of leaves 3-lobed, capsules glabrous, stems hispid, with predominantly simple trichomes, geographic distribution restricted to the Serra do Cabral mountain range. The species is under risk because of habitat fragmentation and exotic species introduction.

We suggest protective measures in the management plan of Serra do Cabral park, focusing against the erosive processes and any environmental changes of anthropogenic order. Therefore, is important there are progressive measures in relation to biodiversity conservation in protected areas, such as Serra do Cipó and Grão Mogol, both of which are part of the geological province of the Espinhaço mountain range where H. mariae is found.

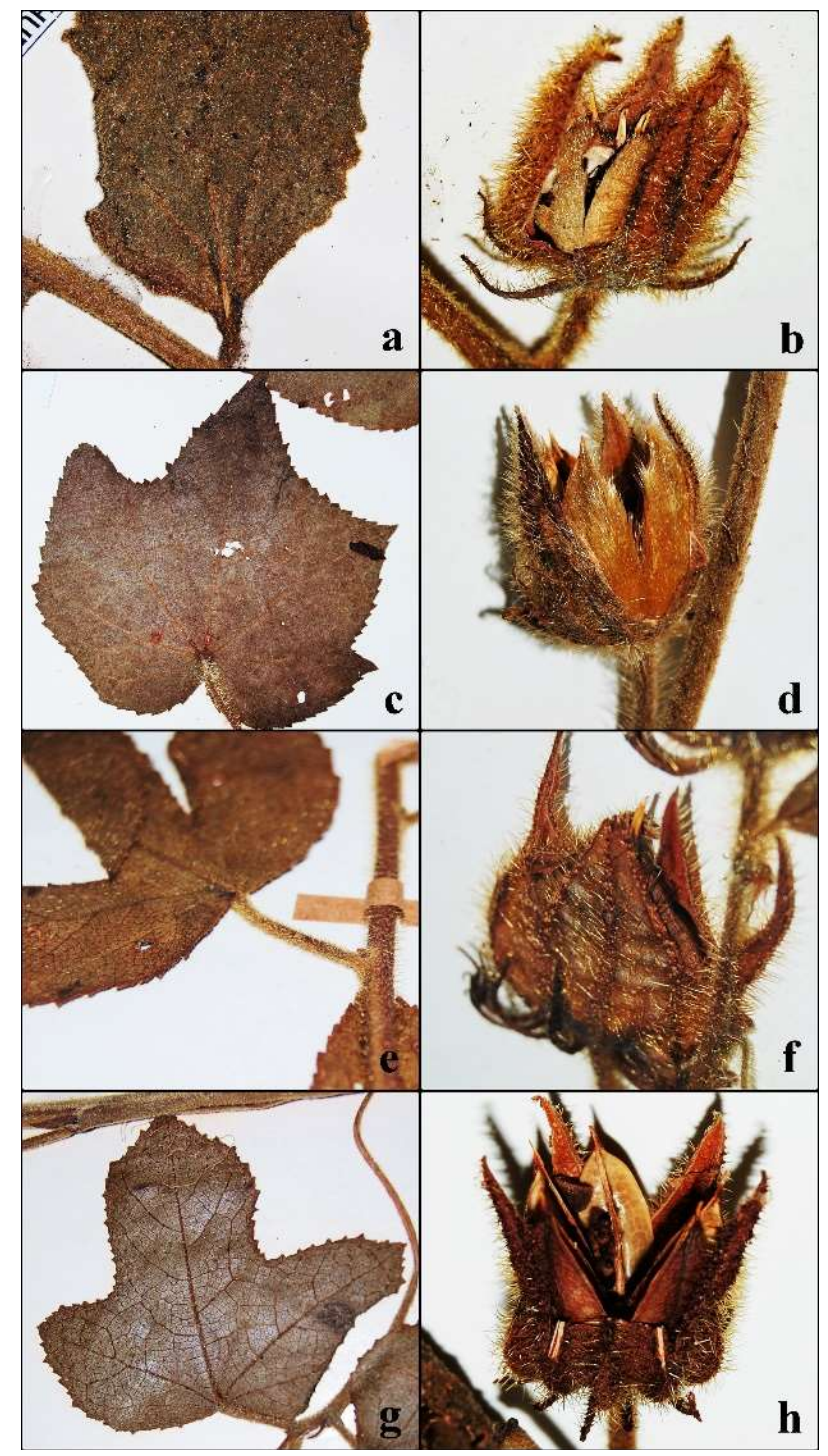

Figure 1: Threatened endemic species of Hibiscus in Minas Gerais. a-b. H. hilarianus - a. leaf, abaxial surface, part of the stem; b. epicalyx, calyx, opened capsule; c-d. H. itirapinensis - c. leaf, abaxial surface; d. epicalyx, calyx, opened capsule, part of the stem. e-f. H. mariae - e. leaf, adaxial surface, part of stem; f. epicalyx, calyx, closed capsule, part of stem. g-h. H. multiformis - g. leaf, abaxial surface; h. epicalyx, part of calyx, opened capsule, axillar seeds.

Hibiscus itirapinensis was listed as endangered species, distributed on southwestern Canastra mountain range with two occurrence sites. The holotype occurrence site in Itirapina city (SP) possibly doesn't has a live specimen anymore, since its area of occurrence was verified in 2016 and its presence was not confirmed (RIGUEIRAL, 2017). It can be recognized by the presence of leaves 3-5-lobed, stem hirsute, with simple trichomes, capsule sericeous, with golden simple adpressed trichomes. Due to its high endemism and 
environmental specificity, is necessary to increase conservation measures for the specie in the management plan of the Serra da Canastra national park.

Hibiscus multiformis was listed as vulnerable, it is distributed over the Diamantina plains with more than five occurrence sites, however, the area of its distribution is not long with $8.000 \mathrm{~km}^{2}$, which justifies its classification. It can be recognized by the presence of leaves 3-5-lobed, stem velutine, capsules glabrous, red, seeds covered by pectin scales. The use of ecological corridors can be implemented as a full measure for the conservation of this species, focusing on the colonization of the $H$. multiformis in a larger space and with greater environmental resilience. It is therefore a conservation measure to be implemented in the management plan of the Parna das Sempre-Vivas in the city of Diamantina, in the Espinhaço mountain range.

Hibiscus hilarianus was listed as vulnerable, it is distributed on western Espinhaço mountain range, from Belo Horizonte to Montes Claros city, with four occurrence sites along its distribution area of about $30.000 \mathrm{~km}^{2}$. It can be recognized by the presence of leaves of cuneate base, with 1(-3) nectary of up to $5 \mathrm{~mm}$ on the abaxial surface, capsules velutinous, covered by starry trichomes, simple trichomes on the upper half or only at the apex. It is important to establish the connectivity of biodiversity in protected areas, such as Serra do Cipó, Serra do Cabral and Grão Mogol, where H. hilarianus and other Hibiscus can be found. Below, the table presents data that supported the species classification.

The IUCN classification tool was useful for expressing the threat status of endemic species of the genus Hibiscus to the Minas Gerais state, however, they not only live in restricted populations, but are susceptible to anthropogenic pressures on the ground and to climate change which tend to decrease isolated populations, whose ecosystems have low environmental resilience, drawing the attention of conservation agencies to protect these areas of occurrence.

Table 1: Conservation status of the species, based on the categorization criteria established by IUCN (2012).

\begin{tabular}{|c|c|c|c|}
\hline Species & Distribution data/Occurrence sites & Category & IUCN pop. Trend \\
\hline H. mariae & About $100 \mathrm{~km}^{2}$, with 1 occurrence site & Critically Endangered & Decreasing \\
\hline H. itirapinensis & About $25.000 \mathrm{~km}^{2}$, with 2 occurrence sites & Endangered & Decreasing \\
\hline H. hilarianus & About $30.000 \mathrm{~km}^{2}$, with 5 occurrence sites & Vulnerable & Decreasing \\
\hline H. multiformis & About $8.000 \mathrm{~km}^{2}$, with $5+$ occurrence sites & Vulnerable & Decreasing \\
\hline
\end{tabular}

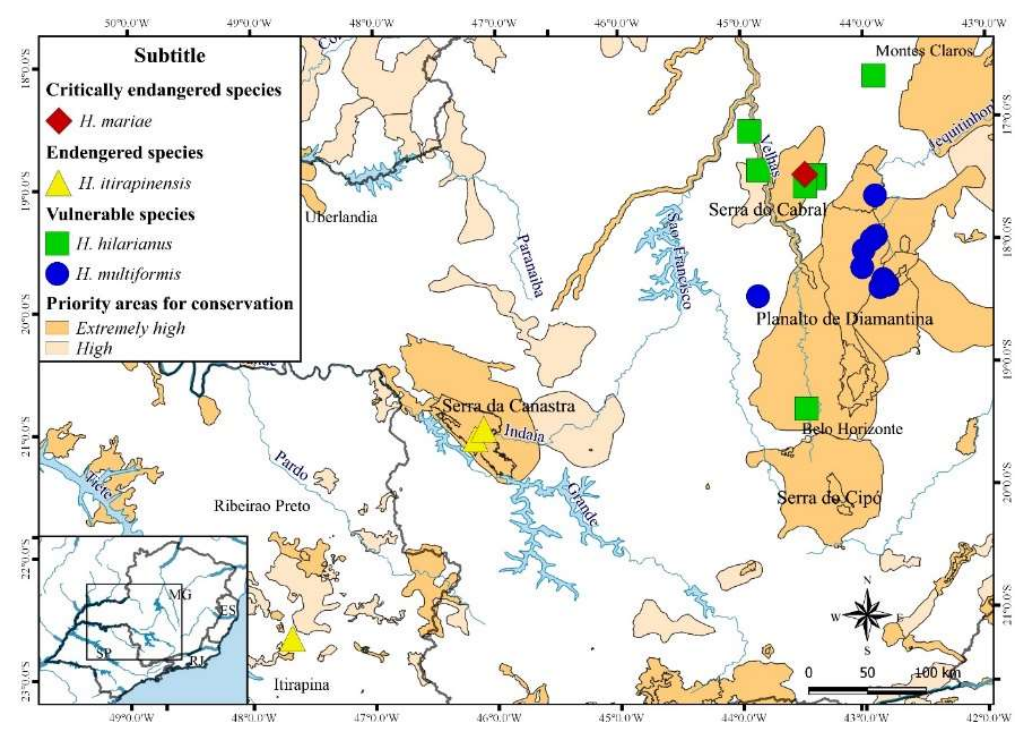

Figure 2: Geographic distribution of threatened endemic species of Hibiscus in Minas Gerais. Priority areas for conservation according to Brazilian Decree no 5.092 of May 21, 2004. 


\section{CONCLUSIONS}

The endemic species of Hibiscus, from Minas Gerais state, adds biodiversity and conservation data of the rocky outcrops vegetation and Cerrado itself, with four small populations distributed in different landscapes of a complex mosaic, on the most representative center of endemism in Brazil, which should be investigated with phylogeographic tools for a better understanding of the evolutionary context of Hibiscus in Minas Gerais.

All the populations of Hibiscus of this study, presented decline in relation to the anthropogenic climatic alteration, biopiracy, irrational ecological tourism, competition with exotic species and the fragmentation of habitat. Is important to include the species in the lists of endangered species of IUCN, MMA, CITES, and other regional and international endangered species lists. Subsequently, conservation measures should be implemented in the management plans of the conservation areas in which the species are found.

The diligence of this scientific work to the IUCN (The International Union for Conservation of Nature) and CITES (the Convention on International Trade in Endangered Species of Wild Fauna and Flora) is urgent to update the conservation status of these four species that are at evident threat.

\section{LIST OF EXSICATES}

Anderson W.R. 8754 (9). Assis-Júnior J.E. 187 (9). Assis M.C. s.n. SPF 61932 (7). Baitello J.B. 1570 (9). Bicudo L.R.H. 257 (6). Brandão M. 24683 (9). Campos W.G. 67 (6). Cordeiro I. 1128 (6). Costa M.T.R. 26 (9). Fernandes Junior A.J. s.n. CESJ 5483 (9). Ferreira G.M.P. 174 (9). Forzza R.C. 4179 (9). Hatschbach G. 47701 (6), 67275 (7), 68987 (7), 72004 (7), 73766 (10), 78849 (7). Heringer 1039 (9), 21953 (7). Krug C.A. 5445 (9). Pereira E. 1507 (10). Romero R. 5152 (9). Rossi L. 1362 (9). Santos M.G. 666 (6). Salimena F.R.G. s.n. CESJ 31288 (7), 1343 (9). Saturnino H. 927 (7). Smith L.B. 6725 (7). Souza A. 2544 (6). Udulutsch R.G. 1267 (10).

\section{REFERÊNCIAS}

BRASIL. Ministério do Meio Ambiente. Conselho Nacional do Meio Ambiente. Decreto no 5.092, de 21 de maio de 2004. Define regras para identificação de áreas prioritárias para a conservação, utilização sustentável e repartição dos benefícios da biodiversidade, no âmbito das atribuições do Ministério do Meio Ambiente. Brasília: DOU, 2004.

BRASIL. Ministério do Meio Ambiente. Lei no 12.651, de 22 de maio de 2012. Dispõe sobre a proteção da vegetação nativa; altera as Leis nos 6.938 , de 31 de agosto de 1981, 9.393, de 19 de dezembro de 1996, e 11.428, de 22 de dezembro de 2006; revoga as Leis nos 4.771 , de 15 de setembro de 1965, e 7.754, de 14 de abril de 1989, e a Medida Provisória no 2.166-67, de 24 de agosto de 2001; e dá outras providência. Brasília: DOU, 2012.

BERGALLO, H. G.; BERGALLO, A. C.; ROCHA, H. B; ROCHA, C. F. D.. Invasion by Artocarpus heterophyllus (Moraceae) in an island in the Atlantic Forest Biome, Brazil: distribution at the landscape level, density and need for control. Journal of Coastal Conservation, v.20, n.3, p.191-198, 2016. DOI: http://doi.org/10.1007/s11852-016-0429-9

ESTEVES, G. L.. Hibiscus: Lista de Espécies da Flora do Brasil. Rio de Janeiro: Jardim Botânico do Rio de Janeiro, 2015.
GONÇALVES, E. G.; LORENZI, H. J.. Morfologia Vegetal: organografia e dicionário ilustrado de morfologia das plantas vasculares. 2 ed. Instituto Plantarum de Estudos da Flora, 2011.

INPE. Instituto Nacional de Pesquisas Espaciais. Sistema de Processamento de Informações Georeferenciadas. 2018.

IUCN. IUCN Red List Categories and Criteria: Version 3.1. 2 ed. IUCN, 2012.

CAMPBELL, C. S.; DONOGHUE, M. J.; KELLOGG, EL. A.; STEVENS, P. F.; JUDD, W. S.. Sistemática vegetal: um enfoque filogenético. 3 ed. Artmed, 2009.

LORENZI, H. J.. Brazilian trees: Book I. 5 ed. Nova Odessa: Publisher Plantarum, 2014.

MATARAZZO, A.; SILVA, C.V.V.; FRAGA, A.; POLISEL, R. T.; GONÇALVES, L. N.. Utilização de Matriz de Avaliação de Impactos ambientais para Conservação Populacional da Amarilis na Serra da Mantiqueira. In: CONGRESSO NACIONAL DE MEIO AMBIENTE, 14. Anais. Poços de Caldas, 2017.

Tropicos. Missouri Botanical Garden. 2017. 
RAPINI, A.; RIBEIRO, P. L.; LAMBERT, S.; PIRANI, J. R.. A flora dos campos rupestres da Cadeia do Espinhaço.

Megadiversidade, 2008.

RIGUEIRAL, L. H. G.. O gênero Hibiscus L. (Malvoideae, Malvaceae) no Sudeste do Brasil. Dissertação (Mestrado) Universidade de Mogi das Cruzes, São Paulo, 2017.

RODRIGUES, V. A.; BUCCI, L. A.; PINHEIRO, L. Z.; SIQUEIRA, H. E.; OLIVEIRA, P. J. D.. Biomas Brasileiros: conservação da biodiversidade, solo, floresta e água. Botucatu: FEPAF, 2017.

SILVA, C. V. V.; SILVA, L. M. S.; TAVARES R.; SILVA, W. S.. Utilização de Características Fitossociológicas e Bioindicadoras no Monitoramento Ambiental e Avaliação de Impacto nas Bacias do Rio Guandu-RJ. In: JORNADA
FLUMINENSE DE BOTÂNICA, 32. Anais. Rio das Ostras: UENF, 2013.

THE FIELD MUSEUM OF NATURAL HISTORY. Species Link. 2012.

TAVARES R.; SILVA, C. V. V.; SILVA, L. M. S.; SILVA, W. S. Comportamento estrutural da vegetação de um trecho da floresta atlântica da ilha grande, RJ. In: JORNADA FLUMINENSE DE BOTÂNICA, 32. Anais. Rio das Ostras: UENF, 2013.

THIERS, B.. Index Herbariorum: A Global Directory of Public Herbaria and Associated Staff. New York Botanical Garden's Virtual Herbarium, 2015. 